\title{
ANALISIS MUATAN NILAI KARAKTER DALAM BUKU TEKS BAHASA INDONESIA KELAS XI KURIKULUM 2013 REVISI 2017
}

\author{
Eries Meilani \\ Universitas Singaperbangsa Karawang \\ eriesmeilani@gmail.com
}

\begin{abstract}
Abstrak: Penelitian ini bertujuan untuk mendeskripsikan: (1) bentuk nilai-nilai karakter, dan (2) penyebaran muatan nilai-nilai karakter dalam setiap bab. Penelitian ini merupakan penelitian deskriptif kualitatif dengan analisis isi (content analysis) yang dilaksanakan melalui beberapa tahap yaitu: (1) pengadaan data; (2) pencatatan data; (3) reduksi; (4) inferensi/penarikan kesimpulan; dan (5) deskripsi hasil penelitian. Sumber data penelitian yaitu buku teks Bahasa Indonesia Kelas XI Kurikulum 2013 Revisi 2017. Sedangkan, objek penelitiannya yaitu nilai-nilai karakter yang terkandung dalam teks atau kalimat yang tersebar pada buku teks. Hasil penelitiannya sebagai berikut. (1) Buku teks Bahasa Indonesia Kelas XI mengandung 18 nilai karakter sesuai dengan pedoman Penguatan Pendidikan Karakter dan Kemdikbud. Nilai-nilai karakter yang paling banyak muncul yaitu bersahabat, komunikatif, disiplin, dan tanggung jawab, sedangkan yang paling sedikit muncul yaitu semangat kebangsaan, cinta damai, dan peduli lingkungan. Karakteristik dari nilai karakter yang muncul yaitu berdiri sendiri, berdampingan dengan karakter lain, dan muncul secara berulang-ulang. (2) Penyebaran muatan nilai-nilai karakter dalam setiap bab cukup merata. Bab I dan III memiliki muatan nilai karakter paling banyak, yaitu 16 nilai, sedangkan Bab VII memiliki muatan nilai paling sedikit, yaitu 9 nilai. Penyebaran nilai karakter diintegrasikan melalui materi pembelajaran, melalui cerita atau contoh teks, dan mempraktikkannya dalam aktivitas pembelajaran.
\end{abstract}

Kata Kunci: pendidikan karakter, nilai-nilai karakter, buku teks, kurikulum 2013

\section{ANALYSIS OF CHARACTER VALUE CONTENT IN TEXT BOOK OF INDONESIAN SUBJECT AT CLASS XI CURRICULUM 2013 REVISION 2017}

\begin{abstract}
This study aims to describe: (1) the shape of the character values, and (2) the distribution of the character values in each chapter. This research is a qualitative descriptive study with content analysis which was carried out in several stages, namely: (1) data procurement; (2) data recording; (3) reduction; (4) inference / drawing conclusions; and (5) a description of the research results. The data source of this research is the Indonesian Language textbook Class XI Curriculum 2013 Revision 2017. Meanwhile, the object is the character values contained in the text or sentences scattered in the book. The results of the research are as follows. (1) Class XI Indonesian text book contains 18 values according to the guidelines of Character Education Strengthening and Ministry of Education and Culture guidelines. The character values that appear the most are communicative friendship, discipline, and responsibility, meanwhile, the least is the spirit of nationality, peace-loving, and caring for the environment. The characteristics of the character values that appear are standing alone, side by side with other characters, and appearing repeatedly. (2) The
\end{abstract}


distribution of character values in each chapter is fairly even. Chapters I and III have the most content of character values, namely 16 values, meanwhile, Chapter VII has the least one, namely nine values. The distribution of character values is integrated through learning materials, showing character values through stories or text examples, and practicing them in learning activities.

Keywords: character education, character values, textbook, curriculum 2013

\section{PENDAHULUAN}

Perkembangan zaman semakin hari semakin maju. Hal tersebut ditandai dengan hadirnya teknologi yang memudahkan aktivitas manusia. Namun, perkembangan zaman yang semakin maju justru menjadi tantangan baru bagi setiap bangsa apakah menjadi bangsa yang memiliki integritas kuat atau semakin tergerus dengan perubahan zaman. Pada kenyataannya, akhir-akhir ini masih banyak orang khususnya para remaja yang melakukan penyimpangan sosial yaitu berupa tindak kekerasan, bullying, menonton video porno, seks bebas, tawuran, narkoba, kecanduan game, mencontek, tidak menghormati guru, dan sebagainya. Hal ini sebagai tanda bahwa sumber daya manusia di Indonesia belum memiliki integritas atau kualitas moral yang baik.

Berdasarkan data dari Komisi Perlindungan Anak Indonesia (Hendarman, 2019), mayoritas penyimpangan sosial yang terjadi di kalangan remaja adalah bullying, kekerasan fisik, dan seks bebas. Kasus tersebut terus meningkat setiap tahunnya. Pelaku dan korban dari kasus tersebut adalah remaja yang berstatus sebagai pelajar. Melihat kenyataan tersebut tentu saja sangat miris. Generasi penerus bangsa yang seharusnya memiliki kualitas moral yang diharapkan, justru bersikap sebaliknya. Memang tidak semua pelajar melakukan hal yang demikian, namun alangkah lebihnya apabila penyimpangan perilaku tersebut sepenuhnya dihilangkan dalam diri peserta didik.

Penyimpangan perilaku peserta didik tentu tidak muncul dengan sendirinya, tetapi dipengaruhi oleh beberapa faktor. Lickona (2013) mengatakan bahwa penyimpangan perilaku oleh remaja salah satunya dipengaruhi oleh media massa. Derasnya arus informasi dari berbagai belahan dunia akan mudah diterima hanya dengan satu jari saja. Usia remaja adalah masa-masa mencari jati diri, maka tidak heran arus informasi dapat mengubah pola pikir dan karakter peserta didik. Sebagaimana yang dikatakan oleh Nadiem Makarim, bahwa era teknologi sejalan dengan derasnya informasi. Apabila remaja tidak memiliki karakter dan integritas kuat, maka dapat membuatnya kehilangan arah.

Lickona (2013) mengatakan bahwa suatu bangsa akan menuju kehancuran apabila terdapat tanda-tanda berikut: (1) meningkatnya tindak kekerasan di kalangan remaja; (2) tindakan curang, seperti menyontek dan korupsi; (3) timbulnya rasa curiga dan kebencian terhadap sesama; (4) rendahnya sikap hormat kepada orangtua dan guru; (5) sikap intoleran; (6) penggunaan bahasa dan kata-kata yang memburuk; (7) sikap merusak diri seperti penggunaan narkoba, alkohol, dan seks bebas; dan (8) rendahnya rasa tanggung jawab. Melihat tanda-tandanya, tampaknya di sekitar kita semakin banyak terjadi hal-hal yang demikian. Maka, diperlukan solusi dan usaha bersama agar bangsa Indonesia terhindar dari jurang kehancuran. 
Untuk memperbaiki kualitas bangsa tentu harus sejalan dengan memperbaiki kualitas moral sumber daya manusia. Dalam hal ini pemerintah telah mengeluarkan kebijakan yang patut diapresiasi yaitu penyelenggaraan pendidikan karakter. Kebijakan tersebut tercantum dalam Perpres Nomor 87 Tahun 2017 (Hendarman, 2019), tentang program Penguatan Pendidikan Karakter (PPK). Selain itu, Kementrian Pendidikan dan Kebudayaan juga mengeluarkan peraturan Nomor 21 Tahun 2015 tentang program Gerakan Pembudayan Karakter di sekolah. Dalam hal ini sekolah memiliki peran penting untuk melaksanakan pendidikan karakter pada saat proses pembelajaraan di dalam maupun di luar kelas.

Adanya peraturan yang dikeluarkan oleh pemerintah menjadikan pendidikan karakter semakin penting untuk dilaksanakan. Hal ini menandakan bahwa pendidikan karakter perlu direalisasikan sebagai upaya menciptakan generasi yang tidak hanya pintar, tetapi juga memiliki kualitas moral yang baik. Apabila generasi bangsa memiliki kepribadian dan akhlak yang baik, maka masa depan bangsa akan cerah dan terhindar dari kehancuran. Mereka akan menjadi fondasi utama untuk menyukseskan bangsa Indonesia di masa mendatang. Oleh karena itu, upaya pemerintah menyukseskan pendidikan karakter juga harus didukung oleh pihakpihak yang berkaitan. Salah satunya adalah guru sebagai ujung tombak dalam pendidikan diharapkan dapat melaksanakan pendidikan karakter dalam proses pembelajaran.

Pendidikan karakter yang diselenggarakan dalam proses pembelajaran bertujuan untuk menghasilkan lulusan yang tidak hanya cerdas tetapi juga berakhlak mulia. Hal ini sejalan dengan tujuan pendidikan Indonesia yang tercantum dalam Undang-Undang tentang Sistem Pendidikan
Nasional Nomor 20 Tahun 2003 pasal 3, yang menyebutkan bahwa pendidikan nasional berfungsi untuk mengembangkan kemampuan dan membentuk watak serta peradaban bangsa yang bermartabat dalam rangka mencerdaskan kehidupan bangsa. Artinya, tujuan pendidikan tidak hanya untuk mencerdaskan pserta didik, tetapi juga membentuk watak sesuai dengan nilai-nilai pancasila. Maka, pendidikan karakter sangat penting dan mendesak untuk dilaksanakan agar mencetak generasi muda yang dapat menghadapi tantangan zaman.

Di Indonesia, pendidikan karakter sebenarnya memang sudah lama diterapkan dalam dunia pendidikan. Tetapi seiring dengan perubahan zaman menjadikan kebijakan dan pelaksanaan pendidikan karakter perlu dilakukan revisi dan inovasi. Sejalan dengan hal tersebut, Kementrian Pendidikan dan Kebudayaan melakukan inovasi dari kurikulum KTSP menjadi Kurikulum 2013. Dalam Kurikulum 2013, pendidikan karakter wajib diintegrasikan pada semua mata pelajaran termasuk dalam pelajaran Bahasa Indonesia. Mata pelajaran Bahasa Indonesia sangat menarik apabila dikaitkan dengan pendidikan karakter. Salah satunya adalah dapat membangkitkan kesadaran peserta didik untuk mencintai bahasa Indonesia sebagai bahasa persatuan.

Salah satu wujud nyata pemerintah dalam menyukseskan pendidikan karakter yaitu dengan menerbitkan buku teks pelajaran yang sesuai dengan Kurikulum 2013. Buku teks pelajaran adalah salah satu komponen penting dalam pembelajaran. Sebagaimana Cunningswort (Normawati, 2015) mengatakan bahwa buku teks pelajaran sebagai salah satu sumber untuk mencapai tujuan umun dan khusus pembelajaran. Hal ini berarti buku teks pelajaran sebagai salah satu komponen penting yang memberikan arah dan bimbingan untuk mencapai tujuan. Pentingnya buku teks pelajaran juga 
tercantum dalam Permendikbud Nomor 2 Tahun 2008 (Astuti \& Wuryandani, 2017), bahwa buku teks pelajaran tidak hanya sekedar memuat materi pembelajaran saja, tetapi harus memuat nilai karakter.

Selama ini masih banyak yang memandang sebelah mata pentingnya buku teks pelajaran. Perlu diketahui bahwa buku teks pelajaran tidak hanya sekadar sumber bacaan, tetapi harus memuat aspek penting lainnya yaitu pengetahuan, keterampilan, dan juga nilai karakter. Maka, dalam penyusunan buku teks pelajaran tidak boleh sembarangan karena dapat mempengaruhi pola pikir dan karakter. Hal ini sejalan dengan Muslich (2010), bahwa buku teks pelajaran harus memenuhi syarat yang positif bagi para pembacanya. Buku teks pelajaran dapat memengaruhi perkembangan minat, sikap sosial, emosi, dan penalaran peserta didik. Hal ini menunjukkan bahwa buku teks pelajaran memiliki kontribusi untuk membentuk karakter peserta didik melalui muatan nilai karakter yang terkandung di dalamnya.

Namun, berdasarkan berita di situs website, buku teks pelajaran yang beredar masih minim akan nilai-nilai karakter bahkan menyajikan bahasa yang tidak pantas bagi peserta didik. Kasus yang pernah terjadi adalah beredarnya buku paket Bahasa Indonesia kelas VI SD yang di dalamnya mengandung unsur pornografi. Hal tersebut muncul dalam salah satu teks cerita pendek yang memuat kisah vulgar. Kasus lain adalah beredarnya buku paket Bahasa Indonesia untuk SMP yang di dalamnya terdapat kata-kata umpatan kasar dalam salah satu kalimat dialog antara kiai dan pencopet. Hal ini tentu saja sangat tidak pantas dibaca oleh peserta didik. Maka, dalam menyusun dan memilih buku teks pelajaran perlu diperhatikan dengan baik sehingga bahan bacaan atau input yang diberikan pada peserta didik juga bernilai positif.
Berdasarkan permasalahan yang terjadi, peneliti merasa sangat perlu untuk menganalisis nilai-nilai karakter yang terkandung dalam buku teks pelajaran. Buku teks yang akan diteliti dalam penelitan ini adalah buku Bahasa Indonesia Kelas XI SMA Kurikulum 2013 Edisi Revisi 2017. Buku tersebut dipilih atas pertimbangan bahwa usia remaja khususnya kelas XI adalah masa-masa mencari jati diri. Pada masa-masa tersebut peserta didik sangat mudah terprovokasi dan terbawa arus oleh lingkungan sekitar. Maka, buku teks pelajaran yang beredar ini diharapkan sudah mengintegrasikan nilai-nilai karakter yang sejalan dengan tujuan pendidikan. Analisis nilai karakter dalam penelitian ini berpedoman pada Penguatan Pendidikan Karakter (PPK) dan Kemendikbud.

\section{METODE}

Penelitian ini merupakan penelitian deskriptif kualitatif yaitu menganalisis dan mendeskripsikan muatan nilai-nilai karakter dalam buku teks pegangan siswa secara mendalam. Adapun metode yang digunakan adalah dengan teknik analisis isi (content analysis) berdasarkan teori Krippendorff yang dilaksanakan melalui beberapa tahap, yaitu sebagai berikut. (1) Pengadaan data, yaitu menentukan unit analisis data yang akan diteliti. (2) Pencatatan data, yaitu peneliti mencatat data-data yang akan diidentifikasi lebih dalam; (3) Reduksi data, yaitu peneliti menghilangkan data-data yang tidak diperlukan atau tidak sesuai dengan yang diteliti; (4) Penarikan kesimpulan, yaitu dilakukan dengan menggunakan kriteria atau pedoman penentuan nilai-nilai karakter; dan (5) Mendeskripsikan data, yaitu peneliti memaparkan hasil temuan.

Objek dalam penelitian ini adalah nilai-nilai karakter yang tersebar dalam buku teks. Subjek penelitian ini adalah buku teks mata pelajaran Bahasa Indonesia Kelas XI SMA Kurikulum 2013 Edisi Revisi 2017 
yang diterbitkan oleh Kemendikbud. Subjek dalam penelitian ini dipilih berdasarkan purposive sampling. Peneliti memilih buku teks pelajaran Bahasa Indonesia Kurikulum 2013 Revisi 2017 karena digunakan pada jenjang SMA/SMK di Indonesia dan merupakan terbitan Kemendikbud sehingga penting untuk diteliti. Data dalam penelitian ini adalah berbentuk kata, frasa, klausa, dan kalimat yang tersebar pada buku teks mata pelajaran Bahasa Indonesia Kelas XI SMA Kurikulum 2013 Edisi Revisi 2017.

Pengumpulan data dilakukan dengan teknik simak dan catat. Peneliti menyimak penggunaan bahasa tulis, kemudian mencatat dan memasukan kalimat yang mengandung nilai karakter ke dalam tabel korpus data untuk mempermudah proses analisis. Instrumen dalam penelitian ini adalah peneliti sendiri (human instrument), yaitu dengan cara memasukan ke dalam rubrik analisis yang disusun berdasarkan landasan teori terkait nilai-nilai karakter. Keabsahan data penelitian ini menggunakan validitas semantik, validitas referensial, dan realibilitas stabilitas. Validitas semantic untuk mengetahui kesesuaian makna teks dengan konteks. Validitas referensial yaitu mengaitkan data-data dengan referensi yang relevan. Sedangkan reliabilitas stabilitas yaitu melakukan pembacaan secara cermat dan tekun untuk mendapatkan data yang konsisten.

\section{HASIL DAN PEMBAHASAN Hasil Penelitian}

Hasil penelitian ini berkaitan dengan bentuk nilai-nilai karakter yang terkandung dalam buku teks mata pelajaran Bahasa Indonesia Kelas XI Kurikulum 2013 Edisi Revisi 2017, serta penyebaran nilai karakter dalam masing-masing Bab yaitu dari Bab I hingga VIII.

\section{Bentuk Nilai-Nilai Karakter}

Berdasarkan hasil analisis, dalam buku teks mata pelajaran Bahasa Indonesia Kelas XI Kurikulum 2013 Edisi Revisi 2017 telah memuat 18 nilai karakter. Selain itu, kemunculan nilai karakter dalam buku teks mata pelajaran Bahasa Indonesia Kelas XI SMA Kurikulum 2013 Edisi Revisi 2017 memiliki frekuensi yang berbeda. Terdapat nilai karakter yang memiliki kemunculan paling banyak, sedang, hingga paling sedikit. Grafik 1 berikut ini adalah ilustrasi mengenai kemunculan 18 nilai-nilai karakter dalam buku teks pelajaran Bahasa Indonesia Kelas XI Kurikulum 2013 Revisi 2017.

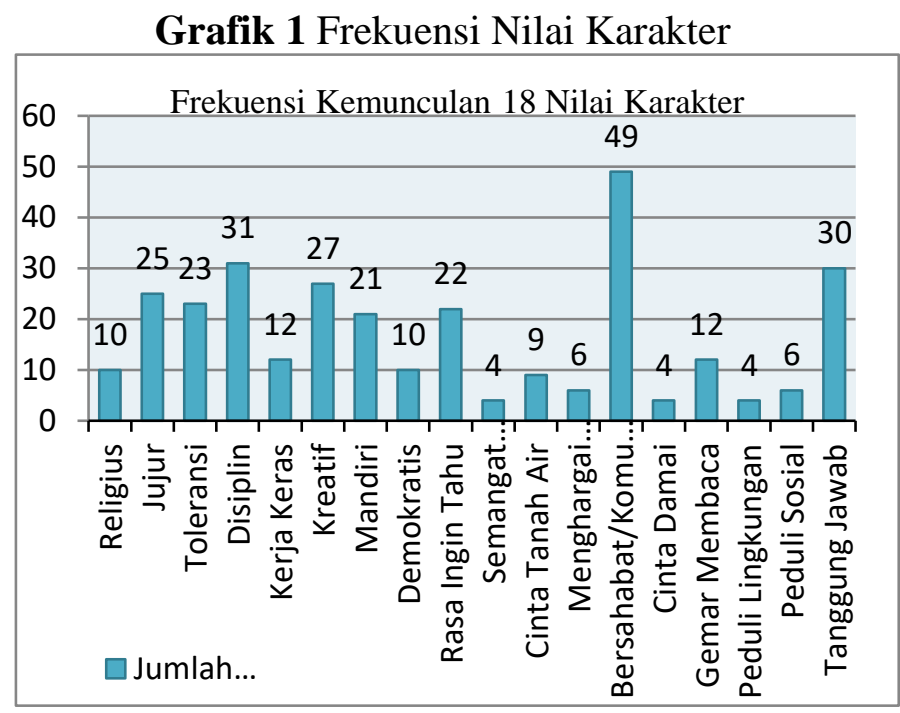

Berdasarkan grafik 1, bersahabat dan komunikatif merupakan nilai karakter yang paling banyak kemunculanya, kemudian diikuti dengan karakter disiplin dan tanggung jawab. Sedangkan nilai karakter yang muncul paling sedikit adalah semangat kebangsaan, cinta damai, dan peduli lingkungan. Jika nilai karakter diurutkan dari yang paling banyak hingga sedikit, maka diperoleh urutan sebagai berikut: (1) bersahabat/komunikatif, (2) disiplin, (3) tanggung jawab, (4) kreatif, (5) jujur, (6) toleransi, (7) rasa ingin tahu, (8) mandiri, (9) kerja keras, (10) gemar membaca, (11) religius, (12) demokratis, (13) cinta tanah air, (14) menghargai prestasi, (15) peduli 
sosial, (16) semangat kebangsaan, (17) cinta damai, dan (18) peduli lingkungan.

Karakter religius dalam buku teks pelajaran Bahasa Indonesia Kelas XI Kurikulum 2013 Edisi Revisi 2017 adalah berwujud lisan dan tindakan yaitu berdoa, beribadah, bersyukur, beramal, beriman, dan taat kepada Allah Swt. Nilai karakter religius diintegrasikan melalui beberapa contoh teks dalam buku. Teks pertama yaitu teks prosedur "Empat Tips Agar Tidak Iri Kepada Orang Lain" yang mengarahkan peserta didik untuk senantiasa bersyukur atas karunia yang Ia miliki. Begitu pun dengan teks cerpen "Matahari Tak Terbit Pagi Ini" dan "Pejuang" yang mengarahkan peserta didik untuk bersyukur atas kehadiran orang-orang sekitar dan umur yang panjang. Wujud taat diintegrasikan melalui teks ceramah "Kesantunan Berbahasa" yang mengingatkan bahwa berbahasa dengan baik dan santun adalah salah satu kewajiban dalam beragama. Kemudian, dalam teks cerpen "Robohnya Surau Kami" dan "Kasus Mencuri Sandal" menampilkan tokoh cerita yang tidak taat pada perintah Allah Swt akan mendapat balasan di dunia dan akhirat.

Nilai karakter religius dalam bentuk berdoa dan beribadah diinegrasikan melalui teks pidato "Hari Pahlawan" dan teks cerpen "Robohnya Surau Kami". Peserta didik diarahkan untuk berdoa kepada Allah Swt apabila meminta pertolongan, memohon ampun, dan meminta suatu hal. Kemudian, peserta didik juga diingatkan beribadah kepada Allah Swt. Selain berdoa dan beribadah, peserta didik juga diingatkan untuk senatiasa beramal shaleh. Nilai karakter religius beramal ini diintegrasikan melalui teks pidato "Hari Pahlawan" dan teks cerpen "Robohnya Surau Kami". Beramal dalam hal ini adalah memberikan bantuan kepada orang yang membutuhkan. Selanjutnya karakter religius bentuk beriman kepada Allah Swt. Beriman dalam hal ini adalah mencintai kebersihan. Kebersihan adalah sebagian dari iman, maka peserta didik diarahkan untuk menjadi pribadi yang cinta kebersihan. Hal ini disampaikan melalui teks eksplanasi "Tentang Jepang" menampilkan masyarakat Jepang yang sangat bersih dan cinta kebersihan. Dengan begitu peserta didik akan terdorong untuk hidup bersih.

Karakter jujur dalam buku teks pelajaran Bahasa Indonesia Kelas XI Kurikulum 2013 Edisi Revisi 2017 adalah dalam bentuk perkataan dan perbuatan yang diintegrasikan melalui contoh teks dan aktivitas pembelajaran. Dalam teks prosedur "Kiat berwawancara Kerja" mengarahkan peserta didik untuk berbicara jujur saat wawancara. Jujur saat wawancara kerja merupakan langkah utama dan sangat penting karena dalam dunia perusahaan membutuhkan orang-orang yang tidak hanya bekerja keras, tetapi juga jujur dalam pekerjaan. Selanjutnya dalam teks "Kasus Mencuri Sandal" menampilkan tokoh pejabat negara yang tidak jujur dalam melaksanakan pekerjaan. Hal ini tentu membuat masyarakt geram sehingga peserta didik memahami bahwa jujur dalam perbuatan juga penting untuk kesejahteraan bersama. Selain itu, nilai karakter jujur dalam bentuk aktivitas pembelajaran adalah jujur dalam mengerjakan tugas, mengoreksi tugas teman, dan mengemukakan pendapat.

Karakter tanggung jawab dalam buku teks pelajaran Bahasa Indonesia Kelas XI Kurikulum 2013 Revisi 2017 adalah dalam bentuk melaksanakan perintah agama, mengerjakan tugas, menjaga lingkungan, berinteraksi dengan sopan dan santun, melakukan suatu hal yang benar, dan menjadi warga negara yang baik. Hal tersebut merupakan tanggung jawab yang harus dilakukan oleh peserta didik dalam kehidupan sehari-hari. Dalam teks pidato "Tentang Jepang" peserta didik bertanggung jawab untuk membersihkan ruang kelasnya. Selain itu, sebagai warga negara yang baik 
peserta didik juga harus mempertahankan tradisi Indonesia, membela keadilan dan menghilangkan pelanggaran dalam negeri, serta menggunakan bahasa yang baik dan benar. Kemudian, bertanggung jawab dalam bentuk melakukan suatu hal muncul dalam teks "Kiat Berwawancara Kerja", "Tetap Semangat Pada Hari Senin", dan "Cara Menghidupkan Komputer".

Karakter kreatif dalam buku teks pelajaran Bahasa Indonesia Kelas XI Kurikulum 2013 Edisi Revisi 2017 adalah berwujud ide dan tindakan menghasilkan sesuatu baru. Nilai karakter kreatif ini diintegrasikan melalui contoh teks dan aktivitas pembelajaran. Pada aktivitas pembelajaran, peserta didik diarahkan untuk berpikir kreatif dalam membuat kalimat, teks, dan suatu karya tulis. Sedangkan dalam contoh teks "Empat Tips Agar Tidak Iri Kepada Orang Lain" peserta didik diarahkan untuk berpikir dan mencari cara baru untuk menjadikan hidupnya sukses. Kemudian pada teks "Lomba Masak" menampilkan tokoh yang berjiwa kreatif, yaitu mampu menciptakan masakan baru dari bahanbahan sederhana.

Karakter disiplin dalam buku teks pelajaran Bahasa Indonesia Kelas XI Kurikulum 2013 Edisi Revisi 2017 adalah disiplin dalam membiasakan diri, menghargai waktu, dan menaati ketentuan dan peraturan yang berlaku. Disiplin dalam membiasakan diri yaitu membaca buku dan membersihkan kelas secara rutin. Disiplin dalam menghargai waktu yaitu peserta didik diarahkan untuk selalu tepat waktu termasuk dalam mengerjakan tugas. Disiplin terhadap ketentuan dan peraturan yaitu peserta didik diarahkan untuk menaati peraturan dan pedoman melakukan suatu kegiatan agar tertib. Kegiatan tersebut berupa bermain drama, membuat proposal, mengoperasikan komputer, menyusun proyek membaca, dan tugas lainnya.
Karakter kerja keras dalam buku teks pelajaran Bahasa Indonesia Kelas XI Kurikulum 2013 Edisi Revisi 2017 adalah kerja keras dalam bentuk mengerjakan tugas, menggapai impian, dan mengatasi hambatan dan rintangan. Peserta didik diarahkan untuk tidak mudah menyerah dalam menghadapi suatu hal yang sulit dan rumit. Misalnya, dalam buku ini peserta didik diarahkan untuk mencari makna dari kata-kata yang dianggap sulit di dalam kamus. Berusaha sebaik mungkin dalam merancang sebuah teks proposal, karya ilmiah, dan juga teks drama yang cukup panjang dan detail. Bekerja keras menggapai impian yaitu peserta didik harus memiliki komitmen untuk mewujudkannya. Hal ini disampaikan dalam teks "Agar Menulis Menjadi Gampang", "Teknik Bermain Gitar", dan "Kiat Berwawancara Kerja".

Karakter mandiri dalam buku teks pelajaran Bahasa Indonesia Kelas XI Kurikulum 2013 Edisi Revisi 2017 adalah dalam bentuk mengerjakan tugas dan melakukan suatu hal. Nilai karakter mandiri mayoritas diintegrasikan pada aktivitas pembelajaran, tetapi ada pula yang melalui materi dan contoh teks yaitu berjudul "Kiat Merawat Rambut Pendek". Dalam aktivitas pembelajaran peserta didik diarahkan untuk tidak bergantung pada orang lain. Terdapat kalimat "gunakanlah bahasamu sendiri", "laporkanlah secara mandiri", dan "buatlah naskah drama berdasarkan pengalamanmu". Selain itu, dalam buku terdapat teks yang mengarahkan peserta didik untuk merawat rambut secara mandiri dan dapat dilakukan di rumah.

Karakter rasa ingin tahu dalam buku teks pelajaran Bahasa Indonesia Kelas XI Kurikulum 2013 Edisi Revisi 2017 adalah dalam bentuk mengerjakan tugas, mencari ilmu, dan memahami suatu teks. Terdapat materi pembelajaran yang mengarahkan peserta didik untuk menyimak ceramah. Hal tersebut merupakan wujud rasa ingin tahu

Analisis muatan nilai karakter dalam buku teks bahasa indonesia kelas xi kurikulum 2013 revisi 2017 
terhadap informasi yang terdapat pada ceramah. Kemudian, karakter gemar membaca dalam buku teks pelajaran Bahasa Indonesia Kelas XI Kurikulum 2013 Edisi Revisi 2017 adalah peserta didik diarahkan untuk menmbuat proyek membaca buku. Proyek membaca ini sebagai salah satu cara untuk menanamkan karakter gemar membaca dalam diri peserta didik. Dengan begitu mereka akan terbiasa untuk membaca buku maupun sumber bacaan lainnya yang bermanfaat bagi dirinya.

Karakter demokratis dalam buku teks pelajaran Bahasa Indonesia Kelas XI Kurikulum 2013 Edisi Revisi 2017 adalah bentuk memberikan kebebasan berpendapat serta mengakui hak dan kewajiban orang lain. Peserta didik diarahkan untuk saling memberikan kesempatan pendapat kepada orang lain, presentasi secara bergiliran dengan kelompok lain, dan mengakui hak dan kewajiban teman-teman di kelas. Selain itu, karakter demokratis juga diintegrasikan melalui contoh teks drama "Lomba Masak", teks cerpen "Gerhana", dan teks eksplanasi "Demonstrasi Massa". Teks tersebut menampilkan tokoh-tokoh yang memiliki sikap demokratis saat berdiskusi dan menyelesaikan suatu permasalahan.

Karakter toleransi dalam buku teks pelajaran Bahasa Indonesia Kelas XI Kurikulum 2013 Revisi 2017 adalah menghargai perbedaan pendapat dan sikap orang lain yang berbeda darinya. Nilai karakter toleransi ini mayoritas muncul pada aktivitas pembelajaran kelompok, yaitu peserta didik diarahkan untuk menghargai perbedaan pendapat dari teman-temannya. Kemudian, pada teks pidato "Berbahasa" juga menampilkan karakter toleransi, yaitu terdapat dua kelompok siswa yang memiliki perbedaan sikap berbahasa. Hal ini agar peserta didik dapat menghargai perbedaan sikap berbahasa sehingga mereka tidak saling mengejek satu sama lain.
Karakter cinta damai dalam buku teks pelajaran Bahasa Indonesia Kelas XI Kurikulum 2013 Edisi Revisi 2017 adalah dalam bentuk perkataan dan perbuatan. Dalam teks prosedur "Kiat Berwawancara Kerja" mengarahkan peserta didik untuk menggunakan bahasa yang baik. Selain itu, penggunaan bahasa yang baik sebagai wujud cinta damai juga disampaikan melalui teks ceramah "Kesantunan Berbahasa". Teks ceramah tersebut mengarahkan peserta didik untuk tidak berbicara dengan kata-kata kasar yang dapat menggores hati seseorang. Dalam cerpen "Gerhana" juga demikian, yaitu menampilkan tokoh yang cinta damai untuk menjaga kerukunan kampung. Dengan disajikan teks tersebut peserta didik akan memahami bahwa bersikap cinta damai terhadap sesama sangat penting untuk dilakukan dalam kehidupan.

Selanjutnya, karakter menghargai prestasi muncul pada teks prosedur "Empat Tips Agar Tidak Iri Kepada Orang Lain”, yaitu mengarahkan peserta didik untuk mau menerima dan mengakui keberhasilan orang lain. Dengan begitu, peserta didik tidak akan merasa sedih tetapi berpacu untuk menjadi lebih baik lagi. Menghargai prestasi tidak hanya sekedar mengakui keberhasilan orang lain, tetapi juga mampu melakukan sesuatu yang bermanfaat bagi masyarakat. Dalam buku ini, peserta didik diarahakan untuk menciptakan karya tulis yaitu proposal, karya ilmiah, teks prosedur, dan teks cerpen yang sarat akan nilai-nilai kehidupan. Selain itu, peserta didik juga diarahakan untuk berbagi hal bermanfaat lainya melalui ceramah dan pidato. Ceramah dan pidato ini berhubungan juga dengan nilai karakter bersahabat komunikatif. Karakter bersahabat komunikatif dalam buku teks Bahasa Indonesia Kelas XI adalah berwujud rasa senang berbicara dengan orang lain, bergaul, dan bekerja sama dalam kelompok.

Nilai karakter peduli lingkungan diintegrasikan melalui dua contoh teks, yaitu 
teks eksplanasi "Banjir" dan teks "Tentang Jepang". Teks tersebut mengarahkan peserta didik untuk senantiasa menjaga lingkungan dari kerusakan, membuang sampah pada tempatnya, dan membersihkan lingkungan sekitar. Sama halnya dengan karakter peduli lingkungan, karakter peduli sosial juga mengarahkan peserta didik untuk peduli terhadap sesama. Hal ini disampaikan melalui teks "Banjir" dan "Gempa Aceh" yang menampilkan korban bencana alam dan membutuhkan bantuan. Kemudian, cerpen "Robohnya Surau Kami" juga demikian yaitu mengarahkan peserta didik untuk peduli terhadap sesama manusia. Karakter peduli sosial juga muncul dalam aktivitas pembelajaran, yaitu menampilkan masalah yang membutuhkan bantuan peserta didik.

Karakter semangat kebangsaan dan cinta tanah air dalam buku teks pelajaran Bahasa Indonesia Kelas XI Kurikulum 2013 Edisi Revisi 2017 adalah dalam bentuk contoh perilaku yang menunjukan semangat kebangsaan. Teks "Demonstrasi Massa", yaitu menampilkan masyarakat yang memiliki semangat kebangsaan dalam memperjuangkan kebenaran dan melawan kemungkaran. Kemudian pada teks "Hari Pahlawan" dan teks cerpen "Pejuang" menampilkan para tokoh pahlawan yang memiliki semangat menggelora dalam membela tanah air. Dalam teks "Kasus Mencuri Sandal" justru menampilkan tokoh yang tidak memiliki rasa cinta tanah air dan semangat kebangsaan. Dengan dihadirkan tokoh seperti itu, peserta didik akan memahami bahwa orang yang bersikap demikian tentu tidak akan disukai oleh orang lain. Selain itu, karakter cinta tanah air juga berhubungan dengan bahasa, yaitu tidak boleh mencampuradukan kaidah bahasa Indonesia dengan bahasa asing. Karakter cinta tanah air juga berupa memperingati hari pahlawan sebagai rasa hormat terhadap perjuangannya melawan para penjajah.

\section{Penyebaran Nilai Karakter dalam Bab}

Terkait dengan penyebaran nilainilai karakter dalam masing-masing Bab, hasil analisis menunjukkan bahwa penyebaran nilai-nilai karakter dalam buku teks pelajaran Bahasa Indonesia Kelas XI Kurikulum 2013 Revisi 2017 adalah cukup merata. Dikatakan cukup merata karena pada masing-masing Bab mengandung nilai karakter yang perbedaannya tidak terlalu besar. Grafik 2 berikut adalah ilustrasi jumlah penyebaran muatan nilai karakter dalam setiap Bab.

Grafik 2 Penyebaran Nilai Karakter

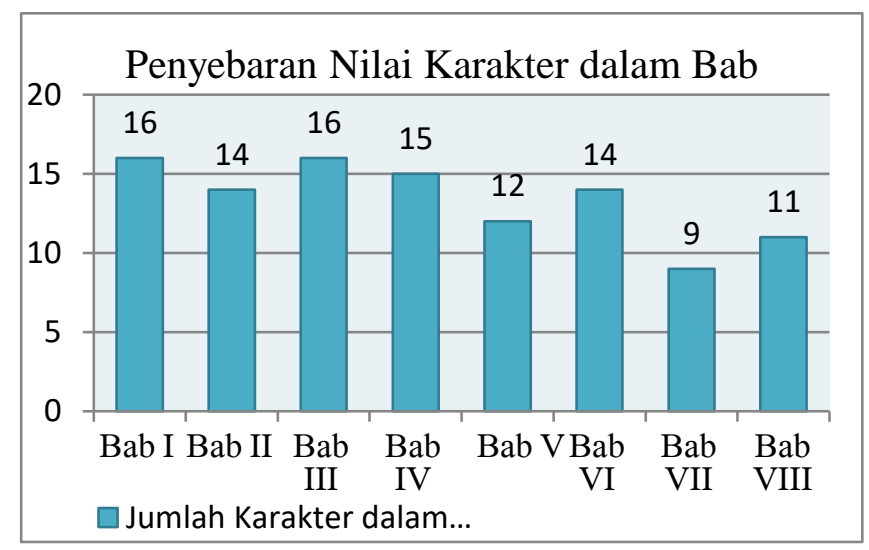

Berdasarkan grafik 2, muatan nilainilai karakter yang diintegrasikan dalam Bab I dan III lebih dominan dibandingkan dengan Bab lainnya. Sedangkan Bab yang mengandung nilai karakter paling sedikit adalah Bab VII. Jika muatan nilai karakter dalam masing-masing Bab diurutkan dari yang paling banyak hingga sedikit, maka diperoleh urutan sebagai berikut: (1) Bab I dan Bab III, (2) Bab IV, (3) Bab II dan Bab VI, (4) Bab V, (5) Bab VIII, dan (6) Bab VII. Adapun penyebaran nilai-nilai karakter dalam buku teks pelajaran Bahasa Indonesia Kelas XI Kurikulum 2013 Revisi 2017 dilakukan dengan cara mengintegrasikan melalui materi pembelajaran pada masingmasing Bab, menunjukkan contoh sikap dan perilaku melalui cerita atau contoh teks, 
serta mempraktikannya dalam aktivitas pembelajaran mandiri dan kelompok.

Pada bagian materi pembelajaran, data yang mengandung nilai karakter disajikan melalui contoh teks pada setiap Bab yaitu (1) teks prosedur, (2) teks eksplanasi, (3) teks ceramah, (4) teks cerpen, (5) proposal, (6) karya ilmiah, (7) teks resensi, dan (8) drama. Selain itu, nilai karakter dalam materi pembelajaran juga diintegrasikan melalui pengantar Bab, Subbab, dan materi yang memaparkan topik pembahasan. Sedangkan pada bagian aktivitas pembelajaran, data yang mengandung nilai karakter berbentuk tugas mandiri dan kelompok sehingga dapat dipraktikan dalam proses pembelajaran.

\section{Pembahasan}

Hasil penelitian menunjukkan bahwa nilai karakter yang terkandung dalam buku teks pelajaran Bahasa Indonesia Kelas XI Kurikulum 2013 Edisi Revisi 2017 sesuai dengan pedoman PPK dan Kemendikbud. Nilai-nilai karakter yang terkandung adalah sebanyak 18 jenis, yaitu religius, jujur, toleransi, disiplin, kerja keras, kreatif, mandiri, demokratis, rasa ingin tahu, semangat kebangsaan, cinta tanah air, menghargai prestasi, bersahabat dan komunikatif, cinta damai, gemar membaca, peduli lingkungan, peduli sosial, dan tanggung jawab. Karakter tersebut adalah cerminan dari lima nilai karakter utama PPK yaitu berhubungan dengan Allah Swt., diri sendiri, sesama, lingkungan, dan negara.

Nilai karakter yang berhubungan dengan Allah Swt., sangat penting dalam diri peserta didik. Peserta didik yang memiliki nilai karakter berhubungan dengan agama akan semakin yakin bahwa semua sikap dan perbuatan yang ia lakukan akan mendapat balasan dari Allah Swt. Maka, peserta didik akan senantiasa untuk berbuat kebaikan dalam kehidupan sehari-hari. Keyakinan yang kuat terhadap Allah Swt. dan agama inilah sebagai landasan utama seseorang dapat bersikap baik dalam kehidupan. Dengan begitu peserta didik tidak akan mudah goyah melakukan kebaikan karena keyakinan yang kuat tersebut.

Karakter yang berhubungan dengan diri sendiri yaitu jujur, tanggung jawab, kreatif, disiplin, kerja keras, mandiri, rasa ingin tahu, dan gemar membaca. Karakter tersebut sangat penting untuk diintegrasikan karena akan menjadikan diri peserta didik memiliki kualitas moral yang baik. Peserta didik yang jujur, tanggung jawab, kerja keras, dan disiplin tentu akan menjadikan dirinya dipercaya dan diterima dalam kehidupan sosial. Apalagi jika peserta didik juga memiliki karakter kreatif, mandiri, memiliki wawasan yang luas, serta berpikir kritis tentu akan disukai orang lain sehingga menjadi nilai lebih untuk dirinya. Hal ini sebagai bekal yang baik bagi peserta didik agar dapat hidup di lingkungan masyarakat.

Nilai karakter tidak hanya berhubungan dengan diri sendiri, tetapi juga berhubungan dengan orang lain. Dalam menjalani kehidupan tentu akan dihadapkan dengan berbagai persoalan. Peserta didik harus memiliki nilai karakter demokratis, toleransi, dan cinta damai agar persoalan dapat terselesaikan dengan baik. Dalam hal ini peserta didik dibiaskan untuk saling menghargai, tidak egois, tidak iri, dan tidak semena-mena dengan orang lain. Nilai karakter yang berhubungan dengan orang lain ini akan sangat indah apabila benarbenar dipraktikan dalam kehidupan seharihari. Setiap orang juga memiliki perbedaan sikap, agama, pandangan, dan pendapat. Maka, dalam menyikapi perbedaan harus dilandasi dengan karakter toleransi, cinta damai, dan demokratis agar kehidupan ini tentram dan damai.

Peserta didik yang memiliki nilai karakter menghargai prestasi diharapkan tidak iri akan keberhasilan orang lain. 
Peserta didik tentu masih dalam masa-masa mencari jati diri, terkadang mudah dipengaruhi oleh orang lain, dan juga merasa iri atas keberhasilan teman. Maka, peserta didik harus ditanamkan karakter menghargai prestasi agar mau mengakui keberhasilan orang lain. Dengan kata lain, peserta didik tidak mudah hancur ketika melihat keberhasilan orang lain, tetapi harus bangkit dan menjadi lebih baik lagi. Karakter bersahabat dan komunikatif juga penting agar peserta didik dapat saling membantu sesama apabila kesulitan belajar, berbagi ilmu atau diskusi untuk menambah wawasan, sehingga dirinya bermanfaat dan dapat berhubungan baik dengan teman.

Seseorang yang memiliki karakter baik tentu akan memperlakukan lingkungan sekitar dengan baik pula. Nilai karakter yang berhubungan dengan lingkungan sekitar yaitu peduli lingkungan dan peduli sosial. Peserta didik harus menyadari bahwa hidup di lingkungan sosial harus memperhatikan keadaaan sekitar. Saling membantu sesama apabila ada yang kesulitan tentu akan mempererat tali persaudaraan. Menjadikan lingkungan bersih dan bebas dari sampah. tidak meludah, merokok, dan membakar sampah sembarangan di lingkungan. Hal ini penting karena untuk menjaga lingkungan alam perlu dimulai dari hal-hal yang kecil sekali pun.

Selanjutnya adalah nilai karakter yang berhubungan dengan negara yaitu cinta tanah air dan semangat kebangsaan. Karakter cinta tanah air dan semangat kebangsaan penting diterapkan pada era milenial saat ini karena perkembangan teknologi yang cepat mampu membuat peserta didik terpengaruh oleh budaya asing. Menerima perbedaan budaya merupakan hal yang wajar, namun jangan sampai peserta didik hanyut mencintai budaya asing. Budaya asing ini lambat laun akan mengikis rasa cinta tanah air dan semangat kebangsaan dalam diri peserta didik. Oleh karena itu, karakter cinta tanah air dan semangat kebangsaan harus ditanamkan agar mereka tidak hanyut mencintai budaya asing.

Masing-masing nilai karakter yang muncul dalam buku tersebut memiliki frekuensi kemunculan yang berbeda-beda. Hal ini terjadi karena terdapat nilai karakter yang diintegrasikan secara berulang-ulang, dan ada pula yang diintegrasikan hanya satu, dua, atau tiga kali di dalam buku. Karakter yang diintegrasikan secara berulang-ulang tentu memiliki kemunculan yang lebih banyak dibandingkan nilai karakter yang muncul hanya satu atau dua kali. Nilai karakter yang berulang-ulang biasanya muncul pada aktivitas pembelajaran mandiri dan kelompok dalam setiap Bab.

Bersahabat/komunikatif adalah nilai karakter yang muncul paling banyak, kemudian diikuti dengan karakter disiplin dan tanggung jawab. Hal ini menunjukkan bahwa karakter bersahabat komunikatif menjadi prioritas utama dalam proses pembelajaran. Buku ini mengarahkan peserta didik untuk bergaul, berkomunikasi, dan menjalin kerja sama dengan teman agar mereka dapat menjalin hubungan sosial dengan baik dalam lingkungannya. Hal ini sangat penting agar peserta didik mampu bersosialisasi dan mencari kawan baru, percaya diri dalam mengeluarkan pendapat, serta bekerja sama dalam mengerjakan tugas kelompok. Oleh karena itu, karakter bersahabat dan komunikatif ini diharapkan dapat melekat dalam diri peserta didik.

Nilai karakter yang kemunculannya paling sedikit yaitu semangat kebangsaan, cinta damai, dan peduli lingkungan. Karakter yang muncul paling sedikit bukan berarti tidak penting. Hal ini terjadi karena diintegrasikan melalui materi pembelajaran dan tidak muncul secara berulang-ulang. Karakter yang kemunculannya sedikit, akan lebih baik apabila dilengkapi dengan contoh perilaku. Dalam hal ini guru sebagai tenaga 
pendidik memiliki kesempatan mengarahkan peserta didik untuk menerapkan nilai-nilai karakter. Misalnya, menumbuhkan karakter peduli lingkungan dapat diwujudkan dengan kegiatan Jumat bersih atau piket kelas. Semangat kebangsaan dapat dilakukan dengan menyanyikan lagu nasional, membiasakan peserta didik untuk menghargai orang lain, bersikap sopan, dan berbicara santun untuk menumbuhkan karakter cinta damai. Dengan begitu, nilai karakter tersebut dapat menjadi suatu kebiasaan dalam kehidupan sehari-hari.

Perlu diperjelas kembali bahwa karakter yang muncul dalam buku teks tersebut memiliki karakteristik yang berbeda sehingga mempengaruhi kemunculannya. Karakteristik tersebut yaitu: (1) Karakter muncul secara berdampingan, (2) muncul secara berulang-ulang, dan (3) berdiri sendiri. Perbedaan tersebut terjadi karena dalam data terdapat kata kunci atau konteks yang mengandung nilai karakter lebih dari satu. Maka, tidak heran apabila karakter muncul secara berdampingan. Untuk nilai karakter yang muncul secara berulang-ulang terjadi karena kata kunci dan konteks dalam data memiliki penyebaran yang merata dalam aktivitas pembelajaran pada setiap Bab. Selanjutnya, nilai karakter yang berdiri sendiri terjadi karena dalam data hanya memiliki kata kunci dan konteks yang mengandung satu nilai karakter saja.

Nilai-nilai karakter yang muncul secara berdampingan menunjukkan bahwa dalam mengintegrasikan nilai karakter ternyata dapat disatupadukan dengan karakter lain. Misalnya, nilai karakter tanggung jawab dan bersahabat/komunikatif melalui aktivitas pembelajaran. Peserta didik diarahkan bekerja sama dalam mementaskan drama bersama teman kelompok. Hal ini adalah wujud karakter bersahabat dan komuniktif karena peserta bekerja sama untuk mementaskan drama sebagus dan sebaik mungkin. Masing-masing anggota kelompok juga memiliki tanggung jawab dalam memerankan tokoh, mengatur latar, serta menyiapkan segala aspek pementasan sehingga drama akan berjalan lancar. Maka, aktivitas pembelajaran tidak hanya berfokus pada aspek kognitif saja, tetapi juga menumbuhkembangkan nilai-nilai karakter.

Adapun nilai karakter yang muncul secara berulang-ulang merupakan wujud pembiasaan dalam aktivitas pembelajaran. Sesuatu yang dilakukan secara berulangulang akan berubah menjadi suatu kebiasaan. Begitu pun dengan nilai karakter yang diintegrasikan secara berulang-ulang. Aktivitas pembelajaran dilaksanakan hampir setiap hari, maka kesempatan untuk menerapkan nilai karakter tersebut semakin besar. Pembiasaan melalui aktivitas pembelajaran yang sarat akan nilai karakter tentu akan membentuk dan memperkuat kepribadian, akhlak, serta moral peserta didik. Maka, dalam mengintegrasikan nilai karakter tidak bisa dilakukan secara singkat tetapi harus berkesinambungan.

Selain bersifat berdampingan dan berulang-ulang, nilai karakter yang muncul juga ada yang berdiri sendiri dalam materi dan aktivitas pembelajaran. Nilai karakter yang berdiri sendiri menandakan bahwa karakter tersebut bersifat mendalam. Dalam hal ini karakter yang disajikan menggunakan beberapa cerita dan contoh teks sehingga peserta didik menjadi sadar, tersentuh, dan tergerak hatinya. Sedangkan karakter yang berdiri sendiri pada aktivitas pembelajaran menandakan bahwa pada pembelajaran lebih berfokus pada satu nilai karakter saja. Dalam hal ini, bukan berarti nilai karakter yang lain tidak penting, tetapi karakter yang difokuskan diharapkan dapat terlihat dan berkembang dalam diri peserta didik.

Hal ini menunjukkan bahwa karakter yang disajikan dalam aktivitas pembelajaran dapat dipraktikan langsung oleh peserta didik. Dengan begitu, pembelajaran dalam kelas tidak hanya semata-mata mengasah 
kemampuan kognitif, tetapi juga membentuk karakter. Sebagaimana Azzet (2014) yang mengemukakan bahwa dalam proses pembelajaran tidak boleh fokus pada satu kecerdasan saja, melainkan harus mengembangkan kecerdasan lain yaitu kecerdasan spiritual dan emosional. Kecerdasan spiritual dan emosional tersebut adalah nilai-nilai karakter dalam diri peserta didik yang harus ditumbuhkembangkan dalam kehidupan sehari-hari.

Hasil temuan penelitian juga menunjukkan bahwa penyebaran nilai karakter dalam buku teks pelajaran Bahasa Indonesia Kelas XI Kurikulum 2013 Edisi Revisi 2017 adalah cukup merata. Hal ini merupakan sesuatu yang baik karena buku teks pelajaran yang saat ini digunakan oleh peserta didik kelas XI SMA/SMK memiliki muatan nilai karakter yang terpenuhi dalam setiap Babnya. Walaupun penyebarannya masih terbilang cukup merata, di mana masih terdapat Bab yang kurang akan nilai karakter dalam materi yang disajikan maupun aktivitas pembelajaran. Hal ini merupakan hal yang wajar karena setiap Bab memiliki topik atau materi pembelajaran yang berbeda sehingga penyebaran nilai karakter disesuaikan dengan materi yang disajikan.

Melihat bahwa nilai karakter dapat diintegrasikan dalam aktivitas pembelajaran, maka peranan pelajaran bahasa Indonesia dalam membentuk karakter peserta didik menjadi sangat penting. Dalam hal ini, nilai karakter pada aktivitas pembelajaran bahasa Indonesia dapat dikaitkan dengan empat keterampilan berbahasa. Hasil penelitian menunjukkan dalam buku teks pelajaran bahasa Indonesia kelas XI terdapat kegiatan yang mengarahkan peserta didik untuk menyimak ceramh dan membaca buku. Menyimak dan membaca buku merupakan salah satu wujud integrasi nilai karakter rasa ingin tahu dan gemar membaca dalam aktivitas pembelajaran.
Keterampilan berbicara dan menulis ditemukan pada aktivitas pembelajaran saat berdiskusi, presentasi, dan mengemukakan pendapat. Hal ini merupakan salah satu wujud karakter komunikatif dan juga percaya diri. Kemudian, keterampilan menulis juga ditemukan dalam aktivitas pembelajaran yaitu menulis suatu teks hasil karya sendiri. Hal ini adalah salah satu wujud karakter kreatif, jujur, dan mandiri. Sebagaimana yang dikatakan Priyatni (2017) bahwa menanamkan karakter dalam diri peserta didik sejalan dengan meningkatkan keterampilan berbahasa.

Selain dikaitkan dengan empat keterampilan berbahasa, nilai karakter juga dapat dikaitkan dengan pelajaran sastra. Dalam buku teks pelajaran Bahasa Indonesia Kelas XI Kurikulum 2013 Edisi 2017 menyajikan pelajaran yang berkaitan dengan sastra yaitu pada Bab IV Teks Cerita Pendek dan Bab VIII Drama. Cerita pendek dan drama merupakan jenis karya sastra yang di dalamnya terdapat nilai moral yang berkaitan dengan kehidupan. Dengan adanya pembelajaran sastra, peserta didik dapat memahami dan meneladani nilai kehidupan manusia. Nilai-nilai itulah yang membantu peserta didik melihat dan memahami realitas kehidupan sosial yang selama ini mungkin belum mereka ketahui.

Berdasarkan pedoman PPK dan Kemendikbud, buku ini sangat layak untuk digunakan dalam proses pembelajaran Bahasa Indonesia. Namun, terdapat satu nilai karakter yang tidak termuat dalam buku teks pelajaran ini, yaitu karakter berjiwa wirausaha. Menurut Azzet (2014), karakter berjiwa wirausaha sangat penting untuk diintegrasikan karena berkaitan dengan tuntutan zaman. Pada saat ini banyak lulusan sekolah yang sulit mendapatkan pekerjaan. Salah satu karakter yang harus diintegrasikan di era milenial ini adalah wirausaha. Karakter berjiwa wirausaha seharusnya dapat disatupadukan dengan 
karakter kreatif dan kerja keras. Peserta didik diarahkan untuk membuat karya atau terobosan baru sehingga suatu saat nanti dapat menciptakan lapangan pekerjaan.

Kemudian karakter toleransi dalam bentuk menghargai ras, suku, budaya, dan agama tidak ada dalam buku teks tersebut. Karakter toleransi yang dimunculkan dalam buku ini hanya berbentuk menghargai perbedaan pendapat dan sikap orang lain. Toleransi dalam menghargai perbedaan ras, suku, budaya, dan agama merupakan sesuatu yang penting. Hal ini penting karena saat ini masih terdapat keributan yang terjadi di masyarakat hanya karena perbedaan ras, suku, budaya, dan agama. Namun, karakter toleransi dalam menghargai perbedaan pendapat juga merupakan sesuatu yang baik dalam proses pembelajaran. Dengan begitu peserta didik akan menghargai perbedaan walaupun dalam ruang lingkup yang kecil.

\section{KESIMPULAN}

Berdasarkan hasil dan pembahasan, dapat disimpulkan bahwa nilai karakter yang terkandung dalam buku teks pelajaran Bahasa Indonesia Kelas XI Kurikulum 2013 Edisi Revisi 2017 telah sesuai dengan pedoman PPK dan Kemendikbud. Nilai-nilai karakter yang muncul paling banyak adalah bersahabat komunikatif, disiplin, dan tanggung jawab. Sedangkan nilai karakter yang paling sedikit adalah semangat kebangsaan, cinta damai, dan peduli lingkungan. Penyebaran muatan nilai-nilai karakter dalam buku teks pelajaran Bahasa Indonesia Kelas XI Kurikulum 2013 Revisi 2017 adalah cukup merata. Masih terdapat Bab yang penyebaran nilai karakternya masih sedikit, tetapi ada pula Bab yang sarat nilai karakter. Adapun penyebaran karakter dilakukan dengan cara mengintegrasikan pada materi pembelajaran, menunjukkan nilai karakter melalui cerita atau contoh teks, serta mempraktikannya dalam aktivitas pembelajaran mandiri dan kelompok.

\section{Saran}

Muatan karakter dalam buku teks pelajaran Bahasa Indonesia Kelas XI Kurikulum 2013 Edisi Revisi 2017 telah teridentifkasi yaitu sebanyak 18 jenis nilai karakter. Berdasarkan hal tersebut, terdapat beberapa saran yang perlu diungkapkan yaitu sebagai berikut.

1. Bagi guru bahasa Indonesia disarankan untuk lebih peka dan peduli terhadap nilai-nilai karakter yang terkandung dalam buku teks pelajaran Bahasa Indonesia. Dalam hal ini, guru memiliki kesempatan untuk mengintegrasikan dan mengembangkan nilai karakter pada diri peserta didik saat proses pembelajaran.

2. Bagi para pengembang buku teks pelajaran bahasa Indonesia disarankan untuk lebih peduli dan teliti dalam mengintegrasikan nilai karakter. Selain itu, perlu ditambahkan nilai karakter yang sejalan dengan perkembangan zaman seperti karakter berjiwa wirausaha.

3. Bagi peneliti selanjutnya disarankan untuk meneliti buku teks pelajaran Bahasa Indonesia Kelas XI pegangan guru. Hal ini agar dapat diketahui kesesuaian nilai karakter antara buku teks pelajaran Bahasa Indonesia pegangan guru dan pegangan siswa.

\section{DAFTAR PUSTAKA}

Astuti, H. P., \& Wuryandani, W. (2017). Analisis Nilai-Nilai Karakter Pada Buku Guru dan Buku Siswa Kelas IV Semester I Sekolah Dasar. Jurnal Pendidikan Karakter, 226-239.

Azzet, A.M. (2014). Urgensi Pendidikan Karakter Di Indonesia. Yogyakarta: Ar-Ruzz Media.

Eriyanto. (2013). Analisis Isi Pengantar Metodologi untuk Penelitian Ilmu Komunikasi dan Ilmu-Ilmu Sosial 
Lainnya. Jakarta: Kencana Prenada Media Group.

Hendarman. (2019). Pendidkan Karakter Era Milenial. Bandung: Remaja Rosdakarya.

Indria, I. (2018). Pembelajaran Bahasa Indonesia Berbasis Kurikulum 2013. Jurnal Penelitian Bahasa Indonesia dan Pengajarannya, 15-167.

Lickona, T. (2013). Educating For Character. Terjemaahan Juma Abdu Wamaungo. Mendidik Untuk Membentuk Karakter. Jakarta: Bumi Aksara.

Mahsun. (2012). Metode Penelitan Bahasa: Tahapan, Strategi, Metode, dan Tekniknya. Jakarta: Rajawali Pers.

Mardikarini, S., \& Suwarjo. (2016). Analisis Muatan Nilai-Nilai Karakter Pada Buku Teks Kurikulum 2013 Pegangan Guru dan Pegangan Siswa Kelas I SD. Jurnal Pendidikan Karakter, 261-274.

Moleong, L. J. (2018). Metodologi Penelitian Kualitatif. Bandung: PT Remaja Rosdakarya.

Mulyasa. (2013). Manajemen Pendidikan Karakter. Jakarta: Bumi Aksara.

Mulyasa. (2013). Pengembangan dan Implementasi Kurikulum 2013. Bandung: PT Remaja Rosdakarya.

Mumpuni, A., \& Masruri. (2016). Muatan Nilai-Nilai Karakter Pada Buku Teks Kurikulum 2013 Pegangan Guru dan Pegangan Siswa Kelas II SD. Jurnal Pendidikan Karakter, 17-28.

Muslich, M. (2000). Dasar-Dasar Pemahaman, Penulisan, dan
Pemakaian Buku Teks. Yogyakarta: Ar-Ruzz Media.

Normawati. (2015). Nilai Pendidikan Karakter Dalam Buku Teks Pelajaran Bahasa Indonesia SMP Daerah Istimewa Yogyakarta. Jurnal Pendidikan Karakter, 48-69.

Pranowo. (2017). Teori Belajar Bahasa Untuk Guru dan Mahasiswa Jurusan Bahasa. Yogyakarta: Pustaka Pelajar.

Priyatni, E. (2017). Desain Pembelajaran Bahasa Indonesia dalam Kurikulum 2013. Jakarta: Bumi Aksara.

Sanjaya, W. (2008). Kurikulum dan Pembelajaran. Jakarta: Kencana.

Saputro, D. (2017). Nilai Karakter Dalam Buku Teks Pembelajaran Bahasa Indonesia Kelas X Kurikulum 2013 Edisi Revisi. Jurnal Pendidikan Karakter, 9-16.

Sulaiman, R. (6 November 2019). Mendikbud Naidem Makarim Jelaskan Pentingnya Pendidikan Karakter Bagi Anak. Diakses 9 April 2020 , dari https://www.suara.com/health/2019/ 11/06/184918/mendikbud-nadiemmakarim-jelaskan-pentingnyapendidikan-karakter-bagi-anak: http://www.suara.com

Sulistiyowati, E. (2013). Pendidikan Karakter Dalam Pembelajaran Bahasa Indonesia. Jurnal Penelitian Pendidikan Islam, 311-30. 
Lampiran: Tabel Frekuensi Kemunculan Nilai-Nilai Karakter

\begin{tabular}{|c|c|c|c|c|c|c|c|c|c|c|c|c|c|c|c|c|}
\hline \multirow[b]{2}{*}{ Dimensi } & \multirow[b]{2}{*}{ Varian } & \multicolumn{8}{|c|}{ Kemunculan dalam Bab } & \multirow[b]{2}{*}{$\sum$} & \multicolumn{3}{|c|}{ Penyebaran } & \multicolumn{3}{|c|}{ Kategori } \\
\hline & & 1 & 2 & 3 & 4 & 5 & 6 & 7 & 8 & & $\begin{array}{c}\mathbf{T} \\
\mathbf{M}\end{array}$ & $\begin{array}{l}\mathbf{H} \\
\mathbf{M}\end{array}$ & $\mathbf{M}$ & $\mathbf{S}$ & $\begin{array}{l}\mathbf{S} \\
\mathbf{d}\end{array}$ & B \\
\hline $\begin{array}{l}\text { Nilai } \\
\text { karakter yang } \\
\text { berhubungan } \\
\text { dengan Allah } \\
\text { Swt. }\end{array}$ & Religius & 1 & - & 4 & 4 & - & 1 & - & - & 10 & $\sqrt{ }$ & & & $\sqrt{ }$ & & \\
\hline \multirow{8}{*}{$\begin{array}{l}\text { Nilai } \\
\text { karakter yang } \\
\text { berhubungan } \\
\text { dengan diri } \\
\text { sendiri. }\end{array}$} & Jujur & 5 & 4 & 4 & 4 & 1 & 2 & 1 & 4 & 25 & & & $\sqrt{ }$ & & $\sqrt{ }$ & \\
\hline & $\begin{array}{l}\text { Tanggung } \\
\text { jawab }\end{array}$ & $\begin{array}{l}1 \\
0\end{array}$ & 5 & 4 & 2 & 3 & 2 & 1 & 3 & 30 & & & $\sqrt{ }$ & & & $\sqrt{ }$ \\
\hline & Kreatif & 7 & 4 & 2 & 4 & 5 & 2 & 1 & 2 & 27 & & & $\sqrt{ }$ & & $\sqrt{ }$ & \\
\hline & Disiplin & $\begin{array}{l}1 \\
0\end{array}$ & 2 & 5 & 1 & 3 & 3 & 4 & 3 & 31 & & & $\sqrt{ }$ & & & $\sqrt{ }$ \\
\hline & Kerja keras & 3 & 2 & 1 & - & 2 & 1 & 2 & 1 & 12 & & $\sqrt{ }$ & & $\sqrt{ }$ & & \\
\hline & Mandiri & $\begin{array}{l}1 \\
0\end{array}$ & - & 2 & 2 & 1 & 2 & 1 & 3 & 21 & & $\sqrt{ }$ & & & $\sqrt{ }$ & \\
\hline & $\begin{array}{l}\text { Rasa ingin } \\
\text { tahu }\end{array}$ & 9 & 1 & 2 & 1 & 3 & 3 & 1 & 2 & 22 & & & $\sqrt{ }$ & & $\sqrt{ }$ & \\
\hline & $\begin{array}{l}\text { Gemar } \\
\text { membaca }\end{array}$ & 4 & 1 & 1 & 1 & 3 & - & 1 & 1 & 12 & & $\sqrt{ }$ & & $\sqrt{ }$ & & \\
\hline \multirow{5}{*}{$\begin{array}{l}\text { Nilai } \\
\text { karakter yang } \\
\text { berhubungan } \\
\text { dengan } \\
\text { sesama. }\end{array}$} & Demokratis & 2 & 1 & - & 1 & 1 & 3 & - & 2 & 10 & & $\sqrt{ }$ & & $\sqrt{ }$ & & \\
\hline & Cinta damai & 1 & - & 2 & 1 & - & - & - & - & 4 & $\sqrt{ }$ & & & $\sqrt{ }$ & & \\
\hline & Toleransi & 3 & 3 & 4 & 4 & 4 & 2 & - & 3 & 23 & & $\sqrt{ }$ & & & $\sqrt{ }$ & \\
\hline & $\begin{array}{l}\text { Menghargai } \\
\text { Prestasi }\end{array}$ & 2 & - & 1 & 1 & 1 & 1 & - & - & 6 & $\sqrt{ }$ & & & $\sqrt{ }$ & & \\
\hline & $\begin{array}{l}\text { Bersahabat/ } \\
\text { Komunikatif }\end{array}$ & 8 & 5 & 7 & 8 & 7 & 5 & 4 & 5 & 49 & & & $\sqrt{ }$ & & & $\sqrt{ }$ \\
\hline \multirow{2}{*}{$\begin{array}{l}\text { Nilai } \\
\text { karakter yang } \\
\text { berhubungan } \\
\text { dengan } \\
\text { lingkungan. }\end{array}$} & Peduli sosial & 1 & 3 & - & 2 & - & - & - & - & 6 & $\sqrt{ }$ & & & $\sqrt{ }$ & & \\
\hline & $\begin{array}{l}\text { Peduli } \\
\text { lingkungan }\end{array}$ & - & 2 & 2 & - & - & - & - & - & 4 & $\sqrt{ }$ & & & $\sqrt{ }$ & & \\
\hline \multirow{2}{*}{$\begin{array}{l}\text { Nilai } \\
\text { karakter yang } \\
\text { berhubungan } \\
\text { dengan } \\
\text { bangsa dan } \\
\text { negara. }\end{array}$} & $\begin{array}{l}\text { Cinta tanah } \\
\text { air }\end{array}$ & 1 & 1 & 6 & - & - & 1 & - & - & 9 & $\sqrt{ }$ & & & $\sqrt{ }$ & & \\
\hline & $\begin{array}{l}\text { Semangat } \\
\text { kebangsaan }\end{array}$ & - & 1 & 1 & 1 & - & 1 & - & - & 4 & $\sqrt{ }$ & & & $\sqrt{ }$ & & \\
\hline Jumlah & & $\begin{array}{l}7 \\
7\end{array}$ & $\begin{array}{l}3 \\
5\end{array}$ & $\begin{array}{l}4 \\
8\end{array}$ & $\begin{array}{l}3 \\
7\end{array}$ & $\begin{array}{l}3 \\
4\end{array}$ & 9 & $\begin{array}{l}1 \\
6\end{array}$ & $\begin{array}{l}2 \\
9\end{array}$ & $\begin{array}{c}30 \\
5\end{array}$ & & & & & & \\
\hline
\end{tabular}

Keterangan:

TM = Tidak Merata $; \quad \mathbf{H M}=$ Hampir Merata $; \quad \mathbf{M}=$ Merata $; \quad \mathbf{S}=$ Sedikit $; \quad \mathbf{S d}=$ Sedang $; \quad \mathbf{B}=$ Banyak 